\title{
PENGARUH KUALITAS LAYANAN DAN PENYEDIAAN FASILITAS TERHADAP KEPUASAN KONSUMEN DI ERA PANDEMI COVID19 (Studi Kasus Penumpang KA PT KAI (Persero))
}

\author{
${ }^{1}$ Ananta Prathama, ${ }^{2}$ Ayunda Nabila Mauliddia, ${ }^{3}$ Daniar Seri Firdausi \\ 1,2,3 Universitas Pembangunan Nasional "Veteran" Jawa Timur \\ prathama.ananta@gmail.com \\ Surabaya, Jawa Timur - Indonesia
}

\begin{abstract}
PT KAl (Persero) is a company engaged in transportation services. The development of transportation modes due to the changing times and the COVID19 pandemic have made transportation companies competing to maintain consumer satisfaction. This study aims to see the effect of service and service influence on customer satisfaction of PT KAI (Persero) train users in the era of the Covid19 pandemic. The sampling method in this study was purposive sampling with a total population of 60 respondents who used PT KAl's train service in the past year or during the COVID 19 pandemic. The data used in this research are primary data and secondary data. Primary data is data taken from questionnaires, while secondary data is data that comes from books, journals or other literature. Data processing methods in this study consisted of editing, scoring, and tabulation. Data analysis technique used in this study was processed through SPSS software (Social Science Statistical Package) which consists of multiple linear regression equations, classical assumption test, multiple coefficients of determination (R2), F test and ttest. The test instrument used in this study is validity and reliability test.
\end{abstract}

Keywords: Customer Satisfaction; Facilities; PT KAl; Service Quality

\begin{abstract}
Abstrak
PT KAI (Persero) adalah perusahaan yang bergerak di bidang layanan jasa angkutan dan transportasi. Berkembangnya moda transportasi akibat perkembangan jaman dan munculnya pandemic COVID19 membuat perusahaan transportasi berlombalomba mempertahanakan kepuasan konsumen. Penelitian ini bertujuan untuk mengetahui pengaruh kualitas layanan dan penyediaan fasilitas terhadap kepuasan konsumen pengguna jasa layanan kereta api PT KAI (Persero) di era pandemi Covid19. Metode pengambilan sampel dalam penelitian ini adalah purposive sampling dengan jumlah populasi adalah 60 responden yang menggunakan jasa layanan kereta api PT KAI dalam satu tahun terakhir atau selama masa pandemic COVID19. Data yang digunakan dalam penelitian berupa data primer dan data sekunder. Data primer merupakan data yang diambil dari kuisioner, sedangkan data sekunder adalah data yang bersumber dari buku, jurnal atau literatur lainnya. Uji instrument dalam penelitian ini yaitu uji validitas dan reliabilitas. Sedangkan teknik analisis data yang digunakan dalam penelitian ini diolah melalui software SPSS 25 yang terdiri dari persamaan regresi linier berganda, uji asumsi klasik, koefisien determinansi berganda $\left(R^{2}\right)$, uji F dan uji t.
\end{abstract}

Keywords: Fasilitas; Kualitas Layanan; Kepuasan Konsumen; PT KAI

Open Access at:http://ojs.uho.ac.id/index.php/PUBLICUHO/index

Journal Publicuho is licensed under a Creative Commons Attribution 4.0 International License. 


\section{PENDAHULUAN}

Pandemi COVID19 atau Virus Corona (Severe Respiratory Syndrome Coronavirus 2/SARSCoV2) merebak dalam skala global termasuk Indonesia merupakan virus yang menyerang sistem pernafasan, Karena wabah pandemi tersebut, berbagai sektor merasakan dampaknya sebagai akibat dari adanya kebijakan penanggulangan dan pencegahan wabah. Salah satu sektor yang banyak mengalami dampaknya adalah pada sektor jasa angkutan dan transportasi. Transportasi berarti mengangkut orang atau barang dengan menggunakan kendaraan atau mesin yang dioperasikan oleh sumber daya manusia guna memudahkan mobilitas orang atau tujuan tertentu dalam aktivitas seharihari.

Kereta api merupakan salah satu moda transportasi yang sering digunakan masyarakat untuk melakukan perjalanan baik dari jarak jauh maupun jarak dekat. Kereta menawarkan banyak hal seperti waktu tempuh yang tepat waktu dan harga yang murah dengan penyesuaian kualitas. Namun dalam situasi pandemi Covid19 seperti ini, beberapa kebijakan ditetapkan untuk melarang penyebaran virus tersebut dengan tetap mendukung mobilitas pengguna yang menggunakan kereta api untuk aktivitas seharihari. Sejalan dengan kondisi saat ini, Perusahaan Kereta Api Indonesia atau PT. Kereta Api Indonesia (Persero) harus mampu mampu menjalankan aktivitas sehariharinya tanpa melepas daripada peraturan pemerintah tentang protocol kesehatan dan tetap menjaga kualitas layanan serta melakukan pengaturan penyediaan fasilitas pendukung untuk menjaga kepuasan penumpang di era pandemic COVID19.

Kualitas pelayanan dapat diartikan sebagai kepedulian perusahaan terhadap pelanggan. Kualitas layanan bersifat dinamis dan selalu berubah sesuai permintaan pelanggan. Namun, perusahaan juga sebetulnya memperhatikan aspek pelanggan yang selalu ingin perusahaan meningkatkan kualitas pelayanannya kepada penumpang. Hal ini akan berdampak pada penumpang, sehingga mereka dapat merasakan nilai dari layanan perusahaan dan akan lebih puas dengan apa yang mereka dapatkan. Kepuasan adalah tingkat perasaan seseorang setelah membandingkan kinerja dengan ekspektasi atau harapannya. (Endrawati \& Juliani, 2018). Sedangkan menurut C.H Lovelock (2007: 102) yang dikutip dalam Wedarini (2013) mengartikan kepuasan adalah keadaan emosi, reaksi pasca pembelian mereka, dan akibatnya dapat berupa kemarahan, ketidakpuasan, kejengkelan, kenetralan, kegembiraan, atau kesenangan. Sedangkan, Hansemark dan Albinsson (2004) dalam Linardi (2020) menjelaskan bahwa kepuasan pelanggan secara keseluruhan menunjukkan sikap terhadap penyedia layanan atau reaksi emosional terhadap perbedaan antara apa yang diharapkan pelanggan dan apa yang mereka terima. Zeithaml, Bitner dan Gremler (2006:117) dalam penelitian Santoso et al., (2015) menyebutkan terdapat lima dimensi pokok kualitas layanan yang digunakan sebagai indicator pengukuran, keandalan, 


\section{Journal Publicuho}

ISSN2621-1351 (online), ISSN 2685-0729 (print)

Volume 4 Number 2 (May-July), (2021)pp. 553-569

Accredited SINTA SK.NOMOR 28/E/KPT/2019

Open Access at:http://ojs.uho.ac.id/index.php/PUBLICUHO/index

DOI: 10.35817/jpu.v4i2.18067

daya tanggap, jaminan, empati dan bukti fisik. Hasil penelitian tersebut menunjukkan bahwa terdapat pengaruh yang signifikan dari kelima indikator tersebut baik secara bersamasama maupun secara parsial terhadap kepuasan konsumen.

Di sisi lain, dari kualitas pelayanan yang baik, fasilitas yang tersedia juga berperan menjadi faktor penentu kepuasan pelanggan. Hal ini sesuai dengan hasil penelitian Tanjung et al., (2018) yang menunjukkan bahwa nilai Fhitung> Ftabel yaitu 42,189> 2,42 dan nilai signifikansi $0,000<0,05$, dimana terlihat bahwa fasilitas umum secara simultan mempunyai pengaruh terhadap kepuasan penghuni. Kompleks Perumahan Beutari Permai. Nilai koefisien korelasi berganda dalam penelitian ini juga merupakan hubungan yang sangat tinggi antara fasilitas umum dengan kepuasan penghuni komplek perumahan Beutari Permai, dengan nilai koefisien korelasi sebesar 0,908.

Konsumen atau pelanggan pada jaman sekarang adalah pelanggan yang kritis yang sangat berhatihati dalam membelanjakan vang. Mereka mempertimbangkan banyak faktor untuk memilih sebuah produk atau jasa. Kualitas pelayanan dan ketersediaan fasilitas menjadi salah satu pertimbangan pelanggan dalam menentukan pilihan. Pada tingkat harga yang hampir sama, semakin lengkap fasilitas yang disediakan, dan semakin baik kualitas pelayanan yang diberikan, maka akan semakin puas pelanggan dan ia akan terus memilih perusahaan tersebut sebagai pilihan prioritas berdasarkan persepsi yang ia peroleh terhadap pelayanan dan fasilitas yang diberikan.

Oleh karena itu, tujuan dari penelitian ini adalah untuk mengetahui kualitas layanan dan penyediaan fasilitas Perusahaan Kereta Api Indonesia (Persero) terhadap kepuasan pelanggan atau penumpang kereta api pada saat terjadinya pandemi Covid19 sehingga dapat mencerminkan penilaian masyarakat terhadap kinerja PT KAI (Persero).

\section{KAJIAN LITERATUR}

\section{Kualitas Layanan $\left(X_{1}\right)$}

Model kualitas layanan yang paling populer dan hingga saat ini banyak digunakan sebagai acuan dalam manajemen jasa dan riset pemasaran adalah model SERVQUAL (Service Quality) yang dikembangkan oleh Parasuraman, Zeithaml, dan Berry (1985,1988, 1990, 1991, 1993), 1994). atau juga dikenal dengan istilah Gap Analysis Mode berkaitan erat dengan model kepuasan pelanggan berdasarkan pendekatan yang telah dikonfirmasi (Oliver, 1997) dan dikutip oleh Tjiptono (2008: 107) dalam (Endrawati \& Juliani, 2018). Menurut Tjiptono dan Gregorius (2005) dalam Nugroho dan Magnadi (2018), terdapat lima dimensi sebagai tolak ukur sebuah kelayakan kualitas layanan diantaranya adalah keandalan (reliability), berwujud (tangibles), ketanggapan (responsiveness), keyakinan (assurance), dan empati (emphaty). Faradisa (2016) juga menjelaskan bahwa didalam kualitas layanan dibedakan menjadi lima dimensi dengan penjelasan sebagai berikut: 
1. Keandalan (reliability): standarisasi pemberian pelayanan akurat, mengutamakan, dan tepat waktu pada konsumen

2. Jaminan (assurance): menumbuhkan kepercayaan konsumen terhadap perusahaan dengan jaminan yang meliputi aspek berdasarkan kapabilitas, keahlian, tata krama, dan bebas dari bahaya atau risiko.

3. Empati (empathy): menumbuhkan empati dengan membangun relasi, komunikasi yang baik, kepedulian pribadi dan pemahaman lebih akan kebutuhan konsumen.

4. Ketanggapan (responsiveness): memberikan pelayanan yang cepat dan tanggap dengan informasi yang baik dan benar

5. Bukti fisik (tangible): dapat ditinjau melalui elemenelemen fisik, fasilitas fisik dan juga alat komunikasi.

\section{Penyediaan Fasilitas $\left(\mathrm{X}_{2}\right)$}

Tjiptono (2001:184) dalam Moha \& Loindong (2016) menjelaskan definisi fasilitas sebagai sumber daya fisik yang harus ada sebelum suatu layanan ditawarkan dan diberikan kepada konsumen. Fasilitas juga bisa disebut sebagai apapun yang memberikan kemudahan bagi konsumen untuk mendapatkan kepuasan. Karena suatu bentuk pelayanan tidak dapat dilihat (kasat mata) dan tidak dapat dirasakan, maka aspek bentuk fisik menjadi ukuran yang cukup krusial dan penting bagi suatu pelayanan. Menurut Tjiptono (2001: 4648) dalam Setiawan et al., (2019) indikator fasilitas ada enam, yaitu:

1. Pertimbangan / perencanaan spasial: aspek seperti proporsi, tekstur, warna, dll. dipertimbangkan, digabungkan, dan dikembangkan untuk merangsang respons intelektual dan emosional dari pengguna atau audiens.

2. Perencanaan Ruang: elemen ini meliputi perencanaan interior dan arsitektur.

3. Perlengkapan/perabotan: berfungsi sebagai saranan yang memberikan kenyamanan, sebagai pajangan atau sebagai infrasturktur pendukung.

4. Pencahayaan dan warna: jenis pewarnaan ruangan dan pengaturan pencahayaan sesuai dengan sifat kegiatan yang dilakukan dan sesuai dengan suasana yang diinginkan.

5. Pesan yang disampaikan secara grafis: tampilan visual, penempatan, pilihan bentuk fisik, pemilihan warna, pencahayaan, simbol atau grafik yang ditujukan untuk tujuan tertentu.

6. Unsur Pendukung: fasilitas yang ditujukan untuk melengkapi dan memberikan kenyamanan lebih terhadap fasilitas utama.

\section{Kepuasan Konsumen ( $Y$ )}

Menurut Zeithaml. et al.(2003: 86) dalam (Ruslim \& Rahardjo, 2016), customer satisfaction is defined as follows: 


\section{Journal Publicuho}

ISSN2621-1351 (online), ISSN 2685-0729 (print)

"Satisfaction is the customer's evaluation of a product or service itself in terms of whether the product or service has met their needs and expectations which are considered to result in dissatisfaction with the product or service."

Hal ini sejalan dengan penjelasan Kotler dan Keller (2007) yang dikutip oleh Matantu et

al., (2020) bahwa kepuasan pelanggan adalah perasaan senang atau kecewa seseorang yang timbul setelah membandingkan kinerja (hasil) produk yang dihasilkan.

Menurut Zeithaml, Parasuraman dan Berry yang dikutip oleh Lovelock in el. (2004) dalam Ruslim \& Rahardjo (2016), dimensi kepuasan pelanggan dibedakan menjadi beberapa jenis, yaitu:

1. Expectations (Harapan): kemampuan perusahaan untuk menyesuaikan (customize) dengan menerapkan protokol Kesehatan sebagai jaminan keselamatan transportasi.

2. Perceived delivery product or service (penyampaian produk atau jasa yang dirasakan): kemampuan untuk melayani konsumen dengan memberikan kenyamanan dan jaminan keamanan atas potensi penyebaran virus melalui penyaringan kondisi penumpang menggunakan surat sehat, dan semacamnya.

3. Confirmation or Disconfirmation (Konfirmasi atau diskonfirmasi): kemampuan perusahaan dalam memenuhi kebutuhan konsumen dengan tujuan agar konsumen tidak kecewa dan merasa puas dengan produk atau jasa yang sesuai dengan janji perusahaan atau sebaliknya.

4. Complaining Behavior (perilaku mengeluh): kapasitas perusahaan untuk menjelaskan umpan balik konsumen yang negatif menjadi positif.

Untuk diketahui bahwa kualitas pelayanan publik, mayoritas di lakukan oleh pemerintah melalui lembaga negara/departemen dan non departemen. Operator di lakoni oleh aparatur/pegawai pemerintah.

Menurut Dwiyanto (2006:56) yang dikutip dari La Ode Muhammad Elwan. (2019) bahwa pemberian pelayanan publik oleh aparatur pemerintah kepada masyarakat (publik) merupakan perwujudan dan fungsi aparatur negara sebagai pelayan masyarakat (abdi), disamping sebagai abdi negara. Dalam konteks ini masyarakatlah sebagai aktor utama (pelaku) pembangunan, sedangkan pemerintah berkewajiban untuk mengarahkan, membimbing serta menciptakan suasana yang menunjang kegiatan-kegiatan dari masyarakat tersebut. Pada kondisi ini aparatur negara dituntut untuk lebih mampu memperbaiki kinerjanya (pelayanan prima) dan diharapkan lebih mampu merumuskan konsep atau menciptakan iklim yang kondusif, sehingga sumber daya pembangunan dapat menjadi pendorong percepatan terwujudnya masyarakat yang mandiri dan sejahtera. Pelayanan yang telah menunjuk kepada aturan formal dianggap telah memenuhi sendisendi pelayanan yang baik dan aparat pelayanan dianggap telah konsisten dalam menerapkan aturan hukum pelayanan, (La Ode Muhammad Elwan, 2019) 


\section{METODOLOGI}

Metode penelitian yang digunakan dalam penelitian ini adalah metode deskriptif kuantitatif. Penelitian ini dilakukan dengan menyebarkan kuesioner kepada pelanggan atau pengguna jasa layanan kereta api dalam satu tahun terakhir atau saat terjadi pandemi COVIDI9. Penelitian ini menggunakan data yang terdiri dari data primer yaitu kuesioner dan data sekunder dari studi pustaka seperti jurnal dan sumber bacaan relevan yang terdapat di Internet. Ada 60 responden dalam penelitian ini. Teknik analisis data yang digunakan dalam penelitian ini adalah teknik analisis regresi linier berganda. Analisis regresi linier berganda digunakan untuk mengetahui pengaruh variabel bebas $X_{1}$ yaitu kualitas pelayanan dan $X_{2}$ yaitu pemberian fasilitas terhadap variabel terikat $(Y)$ yaitu kepuasan pelanggan yang alam hal ini adalah pengguna jasa pelayanan Perusahaan Kereta Api Indonesia (Persero). Dalam penelitian ini digunakan uji parsial (ujit) untuk mengetahui ada tidaknya pengaruh secara parsial variabel independen terhadap variabel dependen. Selain itu, uji F digunakan untuk menguji pengaruh dua variabel independen $X_{1}$ dan $X_{2}$ secara simultan atau simultan terhadap variabel dependen (Y). Teknik pengambilan sampel yang digunakan dalam penelitian ini adalah teknik purposive sampling dengan jumlah sampel yang diperoleh sebanyak 60 responden.

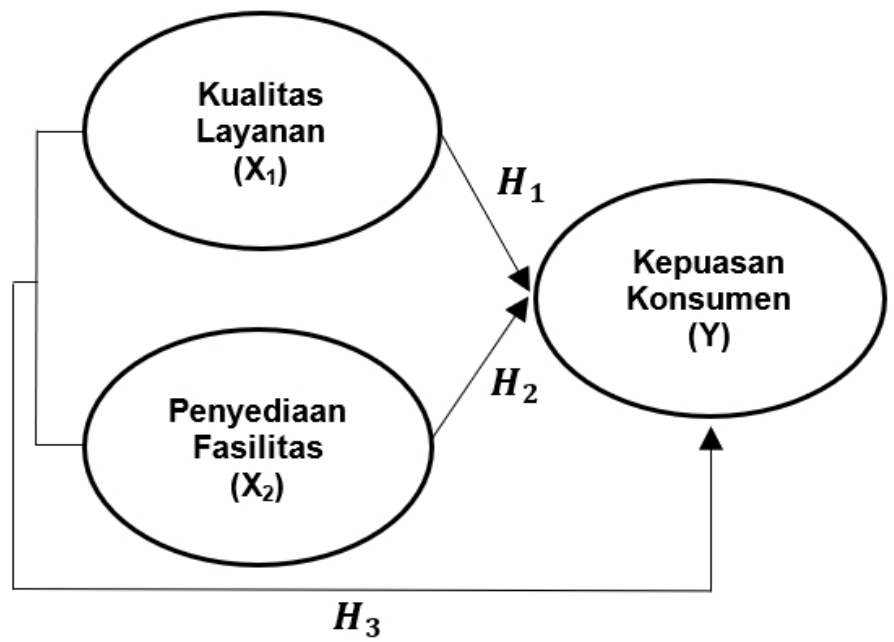

Gambar 1. Kerangka Analisis

$\boldsymbol{H}_{\mathbf{1}}$ : Kualitas layanan berpengaruh signifikan parsial terhadap kepuasan penumpang KA PT KAI (Persero)

$\boldsymbol{H}_{2}$ : Penyediaan Fasilitas berpengaruh signifikan parsial terhadap kepuasan penumpang KA PT KAI (Persero)

$\boldsymbol{H}_{3}$ : Kualitas Layanan dan Penyediaan Fasilitas secara simultan berpengaruh signifikan terhadap kepuasan penumpang KA PT KAI (Persero) 


\section{Journal Publicuho}

ISSN2621-1351 (online), ISSN 2685-0729 (print)

Volume 4 Number 2 (May-July), (2021)pp. 553-569

Accredited SINTA SK.NOMOR 28/E/KPT/2019

Open Access at:http://ojs.uho.ac.id/index.php/PUBLICUHO/index

DOI: 10.35817/jpu.v4i2.18067

\section{HASIL DAN PEMBAHASAN}

\section{Uji Validitas}

Uji validitas menurut Ghozali (2016: 52) dalam Purnawijaya (2019) digunakan untuk mengukur sah atau valid tidaknya suatu angket atau kuesioner. Jika nilai signifikansi menunjukkan pada angka kurang dari 0,05 maka instrument penelitian adalah valid.

Tabel 1. Hasil Uji Validitas Instrumen Penelitian

\begin{tabular}{|c|c|c|c|}
\hline Instrumen & Nilai Korelasi & Sig & Kesimpulan \\
\hline \multicolumn{4}{|c|}{ Kualitas Layanan $\left(X_{1}\right)$} \\
\hline$X_{1.1}$ & 0.501 & 0.000 & VALID \\
\hline$X_{1.2}$ & 0.675 & 0.000 & VALID \\
\hline$X_{1.3}$ & 0.923 & 0.000 & VALID \\
\hline$X_{1.4}$ & 0.501 & 0.000 & VALID \\
\hline$X_{1.5}$ & 0.692 & 0.000 & VALID \\
\hline$X_{1.6}$ & 0.498 & 0.000 & VALID \\
\hline$X_{1.7}$ & 0.912 & 0.000 & VALID \\
\hline $\mathrm{X}_{1.8}$ & 0.880 & 0.000 & VALID \\
\hline $\mathrm{X}_{1.9}$ & 0.768 & 0.000 & VALID \\
\hline$X_{1.10}$ & 0.495 & 0.000 & VALID \\
\hline$X_{1.11}$ & 0.725 & 0.000 & VALID \\
\hline$X_{1.12}$ & 0.715 & 0.000 & VALID \\
\hline$X_{1.13}$ & 0.768 & 0.000 & VALID \\
\hline$X_{1.14}$ & 0.923 & 0.000 & VALID \\
\hline \multicolumn{4}{|c|}{ Penyediaan Fasilitas $\left(\mathrm{X}_{2}\right)$} \\
\hline$X_{2.1}$ & 0.531 & 0.000 & VALID \\
\hline$X_{2.2}$ & 0.389 & 0.002 & VALID \\
\hline$X_{2.3}$ & 0.685 & 0.000 & VALID \\
\hline$X_{2.4}$ & 0.691 & 0.000 & VALID \\
\hline $\mathrm{X}_{2.5}$ & 0.772 & 0.000 & VALID \\
\hline$X_{2.6}$ & 0.634 & 0.000 & VALID \\
\hline$X_{2.7}$ & 0.495 & 0.000 & VALID \\
\hline $\mathrm{X}_{2.8}$ & 0.728 & 0.000 & VALID \\
\hline $\mathrm{X}_{2.9}$ & 0.803 & 0.000 & VALID \\
\hline$X_{2.10}$ & 0.776 & 0.000 & VALID \\
\hline$X_{2.11}$ & 0.845 & 0.000 & VALID \\
\hline$X_{2.12}$ & 0.664 & 0.000 & VALID \\
\hline \multicolumn{4}{|c|}{ Kepuasan Konsumen $(\mathrm{Y})$} \\
\hline$Y_{1}$ & 0.868 & 0.000 & VALID \\
\hline$Y_{2}$ & 0.812 & 0.000 & VALID \\
\hline$Y_{3}$ & 0.889 & 0.000 & VALID \\
\hline$Y_{4}$ & 0.870 & 0.000 & VALID \\
\hline$Y_{5}$ & 0.834 & 0.000 & VALID \\
\hline
\end{tabular}


Tabel 1. menjelaskan setiap indikator yang terdapat pada variabel Kualitas Layanan $\left(X_{1}\right)$, Penyediaan Fasilitas $\left(\mathrm{X}_{2}\right)$, dan Kepuasan Konsumen $(\mathrm{Y})$ memiliki angka besaran pearson correlation antara 0,389-0,923 dan nilai signifikansi dari semua item pertanyaan berada pada alpha $(a)<0,05$. Dengan begitu berdasarkan hasil tabel di atas bisa disimpulkan bahwa semua item pertanyaan yang dipakai dalam penelitian ini dikatakan valid.

\section{Uji Reliabilitas}

Uji reliabilitas adalah pengujian untuk mengukur suatu kuesioner yang merupakan indikator dari variabel atau konstruk. Suatu kuesioner dapat dikatakan reliabel jika jawaban seseorang terhadap peryataan adalah konsisten atau stabil dari waktu ke waktu. Menurut Ghozali (2016: 48) dalam Purnawijaya (2019) suatu konstruk atau variabel dikatakan reliabel jika memiliki nilai Cronbach's Alpha $>0.6$

Tabel 2. Hasil Uji Reliabilitas Variabel Penelitian

\begin{tabular}{lcc}
\hline Variabel & Cronbach's Alpha & Keputusan \\
\hline Kualitas Layanan & 0,924 & Reliabel \\
\hline Penyediaan Fasilitas & 0,880 & Reliabel \\
\hline Kepuasan Konsumen & 0,905 & Reliabel \\
\hline
\end{tabular}

Sumber: Data diolah (2021)

Berdasarkan tabel 2. dapat diketahui bahwa semua variabel yang digunakan dalam penelitian ini reliable dan dapat diuji kembali menggunakan data yang serupa karena masingmasing dari variabel independen dan dependen memiliki nilai Cronbanch's Alpha > 0,6 .

\section{Uji Asumsi Klasik}

\section{Uji Normalitas}

Menurut Menurut Ghozali (2016) dalam Purnawijaya (2019: 154) uji ini dilakukan untuk mengetahui apakah sebaran data berdistribusi normal atau tidak. Uji normalitas menggunakan uji Kolmogorov Smirnov. Nilai pengujian berdasarkan Kolmogorov Smirnov dengan signifikansi $>0,05$, maka dapat disimpulkan bahwa sebaran data berdistribusi normal.

Tabel 3. Hasil Uji Normalitas

OneSample KolmogorovSmirnov Test

\begin{tabular}{lc}
\hline \hline $\mathrm{N}$ & Unstandardized Residual \\
\hline Asymp. Sig. (2tailed) & 60 \\
\hline \multicolumn{2}{c}{ Sumber: Data diolah (2021) }
\end{tabular}

Berdasarkan dari hasil tabel 3. di atas. Nilai residual berdistribusi normal karena nilai signifikansi Kolmogorovsmirnov menunjukan angka 0,200 dimana lebih besar dari 0,05. (0,2>0,05). 


\section{Journal Publicuho}

ISSN2621-1351 (online), ISSN 2685-0729 (print)

Volume 4 Number 2 (May-July), (2021)pp. 553-569

Accredited SINTA SK.NOMOR 28/E/KPT/2019

Open Access at:http://ojs.uho.ac.id/index.php/PUBLICUHO/index

DOI: 10.35817/jpu.v4i2.18067

\section{Uji Multikoliniearitas}

Menurut Menurut Ghozali (2016: 103) dalam Purnawijaya (2019), multikolinearitas dapat diketahui dengan cara penggunaan metode analisis matrik korelasi variabelvariabel independen dengan meninjau dari Tolerance value dan nilai variance inflation factor (VIF). Keduanya menunjukan setiap variabel bebas manakah yang yang dijelaskan oleh variabel bebas lainnya. Nilai cutoff yang umum digunakan adalah nilai tolerance 0,10 atau sama dengan VIF diatas 10. Apabila nilai tolerance melebihi 0,10 atau nilai VIF kurang dari 10 maka dapat dinyatakan bahwa tidak terdapat multikolinearitas antar variabel dalam model regresi.

Tabel 4. Hasil Uji Multikolinearitas

Coefficients $^{a}$

\begin{tabular}{|c|c|c|}
\hline \multirow{2}{*}{ Model } & \multicolumn{2}{|c|}{ Collinearity Statistics } \\
\hline & Tolerance & VIF \\
\hline \multicolumn{3}{|c|}{1 (Constant) } \\
\hline $\mathrm{X} 1$ & .984 & 1.016 \\
\hline $\mathrm{X} 2$ & .984 & 1.016 \\
\hline
\end{tabular}

a. Dependent Variable: Total_Y

Sumber: Data diolah (2021)

Berdasarkan tabel 4. Dikethaui nilai VIF untuk variable Kualitas Layanan $\left(X_{1}\right)$ dan Penyediaan Fasilitas $\left(X_{2}\right)>0,10$ sementara nilai VIF untuk kedua variable dependen yang telah disebutkan $<10,00$. Maka mengacu pada dasar pengambilan keputusan dalam uji multikolinearitas dapat disimpulkan bahwa tidak terjadi gejala multikloiniearitas.

\section{Uji Heteroskesdastisitas}

Menurut Ghozali (2016: 134) dalam Purnawijaya (2019) untuk mendeteksi keberadaan heteroskedastisitas dapat diuji dengan Uji Glejser. Cara yang dilakukan untuk menguji Glejser menggunakan regresi variabel bebas terhadap absolut residual. Model regresi yang tidak terindikasi fenomena heteroskedastisitas adalah nilai signifikansi variabel bebasnya terhadap nilai mutlak residual statistik di atas $a=0,05$

Tabel 5. Hasil Uji Heteroskedastisitas

Coefficients $^{a}$

\begin{tabular}{|c|c|c|c|c|c|}
\hline \multirow{2}{*}{ Model } & \multicolumn{2}{|c|}{$\begin{array}{c}\text { Unstandardized } \\
\text { Coefficients }\end{array}$} & \multirow{2}{*}{$\begin{array}{c}\text { Standardized } \\
\text { Coefficients } \\
\text { Beta }\end{array}$} & \multirow[t]{2}{*}{$\dagger$} & \multirow[t]{2}{*}{ Sig. } \\
\hline & B & $\begin{array}{l}\text { Std. } \\
\text { Error }\end{array}$ & & & \\
\hline 1 (Cons.) & .876 & 1.947 & & .450 & .65 \\
\hline$X 1$ & .0 & .02 & & 1.0 & .290 \\
\hline$\times 2$ & .025 & .026 & .125 & .952 & .345 \\
\hline
\end{tabular}

a. Dependent Variable: Abs_RES

Sumber: Data diolah (2021)

Tabel 5. menunjukkan bahwa nilai dari setiap variabel independen yang terdiri dari kualitas layanan memiliki nilai sig sebesar 0,290 dan penyediaan fasilitas memiliki nilai sig sebesar 
0,345. Dimana kedua nilai tersebut lebih besar dibandingkan 0,05 yang artinya dapat disimpulkan bahwa dari 2 variabel independen tidak terjadi heteroskedastisitas.

\section{ANALISIS REGRESI LINIER BERGANDA}

Analisis data pada penelitian ini menggunakan analisis regresi linier berganda. Menurut Ghozali (2016) dalam Purnawijaya (2019) analisis regresi memiliki tujuan untuk mengetahui arah hubungan antar variabel dependen dengan independen dan juga mengukur kekuatan hubungan antara dua variabel atau lebih. Analisis regresi linier berganda adalah hubungan secara linier antara dua atau lebih variabel independen $(X)$ dengan variabel dependen $(\mathrm{Y})$.

$$
Y=a+\beta_{1} X_{1}+\beta_{2} X_{2}+e
$$

Keterangan:

$$
\begin{array}{ll}
Y & =\text { Kepuasan Konsumen } \\
a & =\text { Koefisien konstanta } \\
X_{1} & =\text { Kualitas Layanan } \\
X_{2} & =\text { Penyediaan Fasilitas } \\
\beta_{1}, \beta_{2} & =\text { Koefisien Regresi } \\
\mathrm{e} & =\text { error atau residual }
\end{array}
$$

\begin{tabular}{|c|c|c|c|c|c|}
\hline \multirow[b]{2}{*}{ Model } & \multicolumn{2}{|c|}{ Unstandardized Coefficients } & \multirow{2}{*}{$\frac{\text { Standardized Coefficients }}{\text { Beta }}$} & \multirow[b]{2}{*}{ t } & \multirow[b]{2}{*}{ Sig. } \\
\hline & $B$ & Std. Error & & & \\
\hline 1 (C) & 3.264 & 2.972 & & 1.098 & .277 \\
\hline $\mathrm{X} 1$ & .075 & .039 & .149 & 1.908 & .061 \\
\hline $\mathrm{x} 2$ & .398 & .040 & .779 & 9.979 & .000 \\
\hline
\end{tabular}

Tabel 6. Hasil Analisis Linier Berganda

Coefficients $^{a}$

a. Dependent Variable: Total_Y

Sumber: Data diolah (2021)

Berdasarkan tabel 6. diatas dapat ditarik model persamaan regresi sebagai berikut:

$$
Y=3,264+0,075 X_{1}+0,398 X_{2}
$$

Model persamaan regresi tersebut diatas dapat dijelaskan sebagai berikut:

1. Kualitas Layanan $\left(X_{1}\right)$ memiliki nilai Koefisien sebesar 0,075. Kesimpulanya kepuasan konsumen PT KAl dipengaruhi secara signifikan oleh kualitas layanan sebesar 1,285 dan nilai tersebut akan bertambah apabila terjadi kenaikan yakni sebesar 0,075.

2. Penyediaan Fasilitas $\left(X_{2}\right)$ memiliki nilai Koefisien sebesar 0,398. Kesimpulanya kepuasan konsumen PT KAl dipengaruhi secara signifikan oleh penyediaan fasilitas sebesar 0,398. 


\section{Journal Publicuho}

ISSN2621-1351 (online), ISSN 2685-0729 (print)

Hal ini menunjukkan bahwa apabila setiap peningkatan variabel $X_{2}$ sebesar $1 \%$, maka kepuasan konsumen meningkat 0,398.

3. Koefisien variable $X_{1}$ dan $X_{2}$ masingmasing memiliki nilai positif yang dapat diartikan bahwa variable penelitian tersebut yaitu kualitas layanan dan penyediaan fasilitas berpengaruh positif dan searah terhadap variable $Y$ yaitu kepuasan konsumen.

4. Nilai konstanta pada persamaan regresi linier berganda sebesar 3,264 yang menunjukkan bahwa jika kualitas layanan dan penyediaan fasilitas bernilai 0 , maka nilai dari kepuasan konsumen negatif sebesar 3,264.

\section{UJI HIPOTESIS}

\section{Uji t (Uji Parsial)}

Menurut Ghozali (2016: 97) dalam Purnawijaya (2019), cara melakukan uji t adalah dengan membandingkan nilai statistik $\nmid$ dengan titik kritis menurut tabel. Apabila nilai statistik $t$ memiliki hasil perhitungan yang lebih tinggi dibandingkan nilai t tabel, maka hipotesis alternatif diterima yang menyatakan suatu variabel independen secara parsial mempengaruhi variabel dependen.

$$
\begin{aligned}
\text { T Tabel } & =(a / 2 ; n k 1 \text { atau df residual }) \\
& =(0,05 / 2 ; 6021) \\
& =(0,025 ; 57) \\
& =2.00247
\end{aligned}
$$

\begin{tabular}{|c|c|c|c|c|c|}
\hline & \multicolumn{2}{|c|}{ Unstandardized Coefficients } & Standardized Coefficients & \multirow[b]{2}{*}{$t$} & \multirow[b]{2}{*}{ Sig. } \\
\hline Model & $B$ & Std. Error & Beta & & \\
\hline 1 (C) & 3.264 & 2.972 & & 1.098 & .277 \\
\hline$X 1$ & .075 & .039 & .149 & 1.908 & .061 \\
\hline$\times 2$ & .398 & .040 & .779 & 9.979 & .000 \\
\hline
\end{tabular}

Tabel 7. Hasil Uji † (Uji Parsial)

Coefficients $^{a}$

a. Dependent Variable: Total_Y

Sumber: Data diolah (2021)

1. Kualitas layanan tidak berpengaruh secara signifikan parsial terhadap kepuasan konsumen karena nilai t hitung lebih kecil dari † tabel $(1,908>2$, 002). Selain itu, pengambilan keputusan uji statistic † juga dapat dilihat dari nilai signifikasi, dimana jika nilai signifikansi kurang dari 0,05 maka HI diterima. Pada tabel 7. tersebut diatas, nilai signifikansi sebesar 0,0610, dimana nilai ini lebih besar (a) sehingga dapat diambil keputusan $\mathrm{H}_{1}$ ditolak atau kualitas layanan secara parsial tidak berpengaruh signifikan terhadap kepuasan konsumen PT KAI.

2. Penyediaan Fasilitas berpengaruh signifikan parsial terhadap kepuasan konsumen PT KAI karena nilai t hitung lebih besar dari t tabel $(9,979>2,002)$. Selain itu, nilai signifikansi sebesar 0,000, dimana nilai ini lebih kecil dari a sehingga dapat diambil keputusan 
bahwa $\mathrm{H}_{2}$ diterima atau penyediaan fasilitas berpengaruh signifikan parsial terhadap kepuasan konsumen PT KAI.

\section{Uji F (Uji Simultan)}

Ghozali (2016) dalam Purnawijaya (2019) memaparkan uji F merupakan uji kelayakan model yang dilakukan untuk menguji kecocokan model sehingga dapat digunakan untuk mengetahui apakah kualitas layanan $\left(X_{1}\right)$ dan penyediaan fasilitas $\left(X_{2}\right)$ memiliki pengaruh positif secara simultan terhadap kepuasan konsumen (Y).

Tabel 8. Hasil Uji $F$ (Uji Simultan)

\begin{tabular}{|c|c|c|c|c|c|}
\hline \multicolumn{6}{|c|}{ ANOVA $^{a}$} \\
\hline Model & Sum of Squares & df & Mean Square & $\mathbf{F}$ & Sig. \\
\hline 1 Regression & 322.902 & 2 & 161.451 & 54.882 & $.000^{b}$ \\
\hline Residual & 167.681 & 57 & 2.942 & & \\
\hline Total & 490.583 & 59 & & & \\
\hline
\end{tabular}

a. Dependent Variable: Total_Y

b. Predictors: (Constant), TotalX_2, Total_X1

Sumber: Data diolah (2021)

Nilai signifikansi $F$ sebesar 0,000 $<0,05$ menunjukkan bahwa kualitas lyanan $\left(X_{1}\right)$ dan penyediaan fasilitas $\left(\mathrm{X}_{2}\right)$ secara bersamasama memiliki pengaruh yang signifikan secara simultan terhadap kepuasan konsumen $(Y)$.

\section{KOEFISIEN DETERMINASI ( $\left.R^{2}\right)$}

Menurut Kuncoro (2013) dalam Purnawijaya (2019) koefisien determinasi (R) menunjukkan tingkat kecocokan hubungan antara variabel bebas dan variabel terikat. Nilai koefisien determinasi berada di antara nol (0) sampai satu (1). Jika nilai koefisien determinasi semakin dekat dengan nol (0), maka semakin jauh hubungan antar variabel bebas dan terikat Begitu pula sebaliknya, apabila nilai koefisien feterminasi semakin dekat dengan satu (1), maka pengaruh kaitan hubungan antara variable semakin kuat.

Tabel 9. Uji Koefisien Korelasi (R) DAN Koefisien Determinasi $\left(R^{2}\right)$

\begin{tabular}{|c|c|c|c|c|}
\hline \multicolumn{5}{|c|}{ Model Summary } \\
\hline Model & $\mathrm{R}$ & R Square & Adjusted R Square & Std. Error of the Estimate \\
\hline 1 & $.811^{a}$ & .658 & .646 & 1.715 \\
\hline
\end{tabular}

Pada tabel 9. dapat diketahui bahwa nilai $R$ sebesar 0,811 atau sebesar $81,1 \%$ yang artinya terdapat hubungan antara variable independent dengan variable dependen sangat karena nilai R berada pada interval 0,801,00. 
Tabel 10. Interpretasi Koefisien Korelasi

\begin{tabular}{ll}
\hline Interval Koefisien & $\begin{array}{l}\text { Tingkat } \\
\text { Hubungan }\end{array}$ \\
\hline $0,000,199$ & Sangat Rendah \\
$0,200,399$ & Rendah \\
$0,400,599$ & Sedang \\
$0,600,799$ & Kuat \\
$0,801,00$ & Sangat Kuat \\
\hline
\end{tabular}

Sumber: Purnawijaya (2019)

Sedangkan nilai $R^{2}$ menunjukkan angka 0,658 dimana nilai sebesar $65,8 \%$ menunjukkan kemapuan variabel kualitas layanan $\left(X_{1}\right)$ dan penyediaan fasilitas $\left(X_{2}\right)$ dalam menjelaskan kepuasan konsumen $(Y)$, sementara sisanya $(100 \% \quad 65,8 \%=34,2 \%)$ dijelaskan oleh variabel lainnya yang tidak ada dalam penelitian ini.

\section{PEMBAHASAN}

\section{Pengaruh Kualitas Layanan $\left(X_{1}\right)$ terhadap Kepuasan Konsumen}

PT Kereta Api Indonesia (Persero) merupakan Badan Usaha Milik Negara (BUMN) Indonesia yang menyelenggarakan jasa angkutan Perkeretaapian dan bisnis usaha penunjang lainnya dengan mengutamakan Integritas, Profesional, Keselamatan Inovasi dan Pelayanan Prima. Dari hal tersebut, dapat diketahui bahwa PT KAI termasuk ke dalam perusahaan milik negara, sehingga dalam hal ini PT KAI termasuk ke dalam salah satu perusahaan yang bergerak di bidang pelayanan public karena dalam operasionalnya PT KAI banyak terkait atau berhubungan dengan masyarakat. Pernyataan tersebut sedsuai dengan definisi yang dipaparkan oleh Ellina dan Lanatan Lina (2009: 16) dalam Salsabila \& Nawangsari (2019), bahwa pelayanan publik pada dasarnya adalah sebuah kegiatan atau rangkaian kegiatan dalam rangka memenuhi kebutuhan dasar sesuai dengan hak - hak sipil setiap negara dan penduduk atas barangnya, jasa dan atau pelayanan administrasi yang diselenggarakan oleh penyelenggara pelayanan publik dalam hal ini adalah pemerintah, baik pemerintah pusat atau pemerintah daerah maupun BUMN/BUMD.

Kebutuhan dasar masyarakat bersifat dinamis dalam artian mengalami perubahan seiring waktu sesuai dengan perkembangan kondisi yang ada. Pada tahun 2020 lalu, pemerintah Indonesia telah mengeluarkan status darurat bencana terhitung mulai tanggal 29 Februari 2020 hingga 29 Mei 2020 terkait pandemi virus Covid19 dengan jumlah waktu 91 hari. Langkahlangkah telah dilakukan oleh pemerintah untuk dapat menyelesaikan kasus luar biasa ini, salah satunya adalah dengan mensosialisasikan gerakan Social Distancing. Konsep ini menjelaskan bahwa untuk dapat mengurangi bahkan memutus mata rantai infeksi Covid19 seseorang harus menjaga jarak aman dengan manusia lainnya minimal 2 meter, dan tidak melakukan kontak langsung dengan orang lain, serta menghindari pertemuan massal (Tuwu, 2020). 
Hal ini membuat PT KAl perlu melakukan penyesuaian terhadap prosedur atau pelaksanaan operasional guna memenuhi kebutuhan dasar sesuai dengan hakhak sipil seperti yang telah dijelaskan dalam definisi pelayanan public sebelumnya. Pemenuhan kebutuhan ini mengacu pada kondisi darurat tanggap wabah Covid19 yang memerlukan perhatian khusus untuk memberikan jaminan keamanan dan keselamatan penumpang dalam menggunakan jasa layanan kereta api Indonesia.

Adapun beberapa penyesuaian kebijakan yang telah dilakukan PT KAI sebagai tanggapan atas situasi darurat Covid19 seperti, a) melakukan penyemprotan cairan disinfektan di seluruh gudang, terminal dan lingkungan kerja unit angkutan barang dimana kegiatan ini dilakukan secara serentak di seluruh area kerja Angkutan Barang Daop dan Divre; b) KAI menyesuaikan syarat naik Kereta Api Jarak Jauh dengan terbitnya SE Gugus Tugas Covid19 No 9 Tahun 2020 tentang kriteria dan persyaratan perjalanan orang dalam masa adaptasi new normal atau kebiasaan baru menuju masyarakat produktif dan aman Covid19. Sehingga setiap penumpang atau konsumen PT KAI harus menyertakan surat keterangan bebas Covid19 saat boarding, dan dalam keadaan sehat dengan syarat suhu tubuh maksimal 37,3 derajat celcius. Selain itu, penumpang atau konsumen wajib menggunakan masker dan menjaga jarak saat di stasiun dan selama perjalanan; c) KAl menyediakan wastafel portabel dan hand sanitizer di titiktitik strategis stasiun dan kereta api untuk menjaga agar pelanggan tetap higienis; c) Secara umum seluruh penumpang kereta api diharuskan dalam kondisi sehat, memiliki suhu tubuh maksimal 37,3 derajat celsius, memakai pakaian lengan panjang atau jaket serta melakukan pemantauan pelaksanaan protokol kesehatan secara ketat; d) Pembersihan seluruh rangkaian kereta seusai beroperasi rutin KAl lakukan menggunakan cairan pembersih yang mengandung disinfektan. KAI juga menugaskan petugas kebersihan di kereta untuk menyeterilkan bagian dalam kereta yang sering tersentuh oleh pelanggan tiap 30 menit sekali; dan e) PT Kereta Api Indonesia (Persero) mendukung penggunaan Gajah Mada Electric Nose Covid19 atau GeNose C19 di layanan KAl untuk mendukung screening Covid19 pada transportasi kereta api.

Pada hasil pengujian statistic deskriptif terhadap aitem pernyataan variable kualitas layanan didapatkan ratarata nilai mean sebesar 4,37 yang menunjukkan bahwa ratarata dari responden menyetujui pernyataan variabel kualitas layanan. Standar deviasi tertinggi terdapat pada aitem pernyataan nomor 5 dan 12 sebesar 0.624 , yaitu "Karyawan PT KAI memberikan pelayanan dengan tanggap sesuai dengan permintaan konsumen" dan "PT KAl memberlakukan pengecekan suhu tubuh dan memantau penerapan protokol kesehatan secara ketat", yang berarti jawaban lebih heterogen atau tidak konsisten dibandingkan indikator lainnya, sedangkan untuk mean tertinggi terdapat pada pernyataan 1 dan 4 dengan nilai mean sebesar 4,53. Nilai mean tertinggi tersebut menunjukkan bahwa mayoritas responden menyetujui bahwa PT KAl mampu 


\section{Journal Publicuho}

ISSN2621-1351 (online), ISSN 2685-0729 (print)

Volume 4 Number 2 (May-July), (2021)pp. 553-569

Accredited SINTA SK.NOMOR 28/E/KPT/2019

Open Access at:http://ojs.uho.ac.id/index.php/PUBLICUHO/index DOI: 10.35817/jpu.v4i2.18067

menginformasikan ketetapan atau kebijakan layanan jasa selama pandemic Covid19 dan karyawan PT KAI mampu mengatasi keluhan atau pertanyaan konsumen. Sementara nilai mean terendah pada aitem pernyataan nomor 8 sebesar 4,18 yang menunjukkan bahwa PT KAI kurang mampu secara jelas menginformasikan adanya asuransi kecelakaan dan halhal yang berkaitan dengan keselamatan penumpang.

Berdasarkan hasil pengujian hipotesis yang telah dilakukan menggunakan uji † (uji parsial) diperoleh hasil bahwa kualitas layanan $\left(X_{1}\right)$ secara parsial tidak memiliki pengaruh signifikan. Hal ini dapat diketahui dari nilai $t$ hitung pada $u j i ~ t ~ l e b i h$ besar dari $t$ tabel. Berdasarkan hal ini, maka hipotesis pertama $\left(\mathrm{H}_{1}\right)$ ditolak.

Hasil analisis menunjukkan bahwa kualitas layanan tidak berpengaruh signifikan namun memiliki arah pengaruh yang positif terhadap kepuasan konsumen. Arah pengaruh positif ini ditunjukkan oleh nilai beta yang positif, yaitu 0,075. Arah pengaruh yang positif menunjukkan adanya pengaruh searah yang menunjukkan apabila kualitas layanan meningkat maka akan meningkatkan kepuasan konsumen dan sebaliknya. Hal ini menunjukkan bahwa apabila PT KAI ingin meningkatkan kepuasan konsumennya, maka sangat penting bagi PT KAI untuk meningkatkan kualitas layanan yang diberikan secara berkelanjutan sesuai dengan kedinamisan kebutuhan masyarakat atau publik.

Hasil penelitian ini tidak sejalan dengan temuan Faradisa et al., (2016) yang menunjukkan adanya pengaruh signifikan positif dengan minat beli ulang konsumen. Minat beli ulang konsumen mencerminkan tingginya tingkat kepuasan konsumen sehingga mempengaruhi preferensi pembelian. Dalam temuan tersebut dipaparkan bahwa semakin tinggi kualitas layanan yang diberikan maka semakin tinggi minat beli ulang konsumen. Selain penelitian oleh Faradisa, et. al (2016), penelitian oleh Kadir et al., (2018) juga menunjukkan hasil penelitian serupa dimana kualitas Iayanan oleh PDAM di Kota Kendari dapat meningkatkan kepuasan pelanggan PDAM melalui nilai pelanggan. Apabila kualitas layanan yang dirasakan pelanggan baik, maka nilai yang diperoleh atas pelayanan yang diberikan PDAM juga baik sehingga pelanggan mempersepsikan adanya nilai yang lebih hingga merasa puas.

\section{Pengaruh Penyediaan Fasilitas $\left(X_{2}\right)$ terhadap Kepuasan Konsumen}

Pada hasil pengujian statistic deskriptif terhadap aitem pernyataan variable penyediaan fasilitas didapatkan ratarata nilai mean sebesar 4,35 yang menunjukkan bahwa ratarata dari responden menyetujui pernyataan variabel pernyataan variabel. Standar deviasi tertinggi terdapat pada aitem pernyataan nomor 7 sebesar 0.854, yaitu "Menyediakan peralatan yang digunakan dalam kondisi darurat di dalam gerbong kereta", yang berarti jawaban lebih heterogen atau tidak konsisten dibandingkan indikator lainnya, sedangkan untuk mean tertinggi terdapat pada pernyataan 5 dengan nilai mean sebesar 4,57. Nilai mean 
tertinggi tersebut menunjukkan bahwa mayoritas responden menyetujui bahwa PT KAI menyediakan fasilitas berupa thermometer tembak untuk pengecekan suhu tubuh saat boarding pass. Sementara nilai mean terendah pada aitem pernyataan nomor 1 sebesar 4,02 yang menunjukkan bahwa mayoritas responden belum menilai adanya konsistensi dari PT KAI dalam menerapkan warna tema sebagai identitas.

Hasil pengujian yang dilakukan pada variable dependen kedua yaitu penyediaan fasilitas menunjukkan hasil yang berbeda dengan kualitas layanan. Penyediaan fasilitas memiliki hubungan signifikan parsial terhadap kepuasan konsumen. Hal ini bisa diketahui melalui tabel hasil uji $\dagger$ dengan nilai $\dagger$ hitung lebih kecil daripada † tabel, dan diperkuat dengan nilai signifikansi sebesar 0,000 dimana nilai tersebut lebih kecil dari 0,05 yang artinya $\mathrm{H}_{2}$ pada penelitian ini diterima.

Hasil penelitian ini sejalan dengan hasil penelitian Moha \& Loindong (2016) dimana hasil uji hipotesis menunjukkan bahwa variabel fasilitas memiliki pengaruh yang signifikan positif terhadap kepuasan konsumen Hotel Yuta di Manado.

\section{KESIMPULAN}

Berdasarkan hasil dan pembahan, maka dapat disimpulkan sebagai berikut:

1. $H_{1}$ ditolak sehingga kualitas layanan secara parsial tidak berpengaruh signifikan terhadap kepuasan konsumen, namun memiliki arah pengaruh positif yang ditunjukkan oleh nilai beta sebesar 0,075 sehingga apabila kualitas layanan meningkat maka kepuasan konsumen juga akan meningkat dan sebaliknya.

2. $\mathrm{H}_{2}$ diterima sehingga penyediaan fasilitas memiliki hubungan signifikan parsial terhadap kepuasan konsumen.

3. $\mathrm{H}_{3}$ diterima sehingga kualitas layanan dan penyediaan fasilitas secara simultan berpengaruh signifikan positif terhadap kepuasan konsumen.

\section{SARAN}

1. PT KAl diharapkan mampu terus mempertahankan, meningkatkan serta menginovasi kualitas layanan dan penyediaan fasilitas sesuai dengan perkembangan yang ada pada masyarakat sehingga mampu mewujudkan visi dan tujuan perusahaan yang salah satunya adalah memberikan pelayanan prima sebagai sector pelayanan publik dalam lingkup BUMN.

2. Untuk peneliti selanjutnya, mengingat pentingnya moda transportasi kereta api dan dinamisnya kebutuhan masyarakat tergantuung pada situasi dan kondisi yang ada, maka diharapkan peneliti di masa yang akan datang dapat menemukan variablevariabel lain yang mana dapat membantu menemukan strategi dan penyesuain kebijakan pelayanan public untuk dapat memenuhi kebutuhan masyarakat secara tepat guna dan tepat sasaran. 


\section{Journal Publicuho}

ISSN2621-1351 (online), ISSN 2685-0729 (print)

\section{REFERENSI}

Endrawati, D., \& Juliani, R. D. (2018). Hubungan Kualitas Layanan dengan Kepuasan Pelanggan PT. Indoguna Utama Semarang. Majalah IImiah Inspiratif, 3(6).

Faradisa, I., Budi, L., \& Minarsih, M. M. (2016). Analisis Pengaruh Variasi Produk, Fasilitas, dan Kualitas Pelayanan Terhadap Minat Beli Ulang Konsumen pada Indonesian Coffeeshop Semarang (ICOS CAFÉ). Journal of Management, 2(2), 1-13.

Kadir, A., Basri, M., \& Rodi, R. (2018). Pengaruh Kualitas Pelayanan Terhadap Kepuasan, Nilai, Kepercayaan Dan Loyalitas Pelanggan Rumah Tangga Pada Perusahaan Daerah Air Minum Kota Kendari. Journal Publicuho, 1 (1), 28.

La Ode Muhammad Elwan. (2019). PROBLEM BIROKRASI DALAM MENINGKATAN PELAYANAN PUBLIK PADA SEKRETARIAT DAERAH KABUPATEN MUNA. In Copyright@2019 Journal PUBLICUHO Faculty of Social and Political Sciences Halu Oleo University (Vol. 2). Retrieved from http://ojs.uho.ac.id/index.php/PUBLICUHO

Linardi, E. (2020). Pengaruh Service Quality Terhadap Customer Loyalty Dengan Overall Customer Satisfaction Sebagai Variabel Intervening Di BCA Rungkut Surabaya. Jurnal Strategi Pemasaran, 7(1).

Matantu, R. N., Tampi, D. L., \& Joane. V, M. (2020). Kualitas Pelayanan Terhadap Kepuasan Konsumen Hotel Gran Puri Manado. Productivity, 1 (4), 355-360.

Moha, S., \& Loindong, S. (2016). Analisis Kualitas Pelayanan Dan Fasilitas Terhadap Kepuasan Konsumen Pada Hotel Yuta Di Kota Manado. EMBA: Jurnal Riset Ekonomi, Manajemen, Bisnis Dan Akuntansi, 4(1), 575-584.

Nugroho, A., \& Magnadi, R. H. (2018). Pengaruh Kualitas Layanan Terhadap Kepuasan Pelanggan Jasa Pengiriman Lazada Express Saat Harbolnas Di E-Commerce. Diponegoro Journal of Management, 7(4), 1-1 1.

Purnawijaya, F. M. (2019). Pengaruh Disiplin Kerja Dan Fasilitas Kerja Terhadap Kinerja Karyawan Pada Kedai 27 Di Surabaya. AGORA, 7(1), 287221.

Ruslim, T. S., \& Rahardjo, M. (2016). Identifikasi Kepuasan Konsumen Ditinjau Dari Segi Harga Dan Kualitas Pada Restoran Abuba Steak Di Greenville. Jurnal Ilmiah Manajemen Dan Bisnis, 2(1), 51-65.

Salsabila, A. K., \& Nawangsari, E. R. (2019). INOVASI PELAYANAN simPADU-PMI DALAM MENINGKATKAN KUALITAS PELAYANAN (Unit Pelaksana Teknis Pelayanan Dan Perlindungan Tenaga Kerja Indonesia (UPT P2TK) Provinsi Jawa Timur). PUBLIC ADMINISTRATION JOURNAL, 2(7), 163-178.

Santoso, A., Fauzi, A., \& Sunarti. (2015). Pengaruh Kualitas Pelayanan terhadap Kepuasan Pelanggan (Survei Pada Penumpang Kereta Api Argo Bromo Anggrek Jurusan Surabaya-Jakarta). JAB: Jurnal Administrasi Bisnis, 21 (1), 1-7.

Setiawan, R., Kosasih, K., \& Sudrajat, A. (2019). Pengaruh Lokasi Dan Fasilitas Terhadap Kepuasan Pelanggan Limasan Kafe Karawang. Buletin Studi Ekonomi, 24 (2), 167-171.

Tanjung, F. A., Afifuddin, M., \& Isya, M. (2018). Analisis Ketersediaan Fasilitas Umum Terhadap Kepuasan Penghuni Komplek Perumahan Beutari Permai Desa Bayu Kecamatan Darul Imarah Kab. Aceh Besar. JARSP: Jurnal Arsip Rekayasa Sipil Dan Perencanaan, 1 (2), 6979.

Tuwu, D. (2020). Kebijakan Pemerintah Dalam Penanganan Pandemi Covid-19. Journal Publicuho, 3(2), 267-278.

Wedarini, N. M. S. (2013). Pengaruh Kualitas Produk Terhadap Kepuasan dan Loyalitas Pelanggan Telkom Flexi. E-Jurnal Manajemen Universitas Udayana, 2 (2), 495-512. 